\title{
Toward a Venture Capital-Backed Entrepreneurship Model in Brazil
}

\author{
Caio Ramalho ${ }^{1}$ \\ caio.ramalho@fgv.br
}

First Draft: May, 2010

This Draft: August, 2010

\begin{abstract}
It is well documented venture capital's positive impact on creation and development of highly successful innovative companies worldwide. Venture capital not only provides funding to startups and SMEs (small and medium enterprises) that usually have financing gap, especially in emerging markets, but also brings a whole package of valuable resources that reduces companies' mortality rates.
\end{abstract}

Using quantitative data obtained from an empirical survey as background, this paper discusses the role of venture capital in the success of innovative startups and SMEs, and it examines if, and to what extent, venture capitalists are supporting the entrepreneurial activity in Brazil.

I focused on the portfolio companies analyzes and confirmed the hypothesis that the venture capital industry has been supporting entrepreneurship in Brazil. Second, I identified an important evidence of a venture capital's positive impact on economic activity, especially the capital market. Third, it became clear that venture capital-back entrepreneurship is highly concentrated in the Southeast region. And fourth, I identified that private equity expansion is also playing a key role on that dynamics.

As consequence, I conclude that the venture capital (and private equity) industry has been very important to build an enormously dynamic and strong local entrepreneurial economy. Its committed capital grew 50\% per year between 2005 and 2008 to achieve US\$27 billion, which invested US\$11 billion, which employs 1,400 professionals (75\% with post-graduate degrees) and maintains 482 portfolio companies, mostly SMEs. In addition, venture capital-backed companies represented one third of the IPOs that occurred in Brazil between 2004 and 2008 (approximately US $\$ 15$ billion).

Keywords: Venture Capital, Private Equity, Entrepreneurship, Innovation, Brazil

\section{Introduction}

Throughout the years, innovation has been a key factor in world's economic growth due to the increase in companies' productivity (Schumpeter, 1934) and it has affected all the five forces that govern competition in any industry (Porter, 1979). In the United States, startups and SMEs (small and medium enterprises) creation has leveraged and empowered its economic development and competitiveness, creating the majority of new jobs in the economy (Porter 1990; Gompers 1994).

Regardless their importance to economy, startups and SMEs usually don't have access to the proper resources required, especially during their initial stage of lifecycle (Gompers, 1994; Pacheco and Spritzer, 2009). In emerging markets this framework is highlighted, and according to Andreassi and Siqueira (2006) lack of financing is one of startups' main mortality reasons in Brazil compared to developed countries. Bosma and Levie (2010) shows that companies' difficult to obtain funding explains $10 \%$ to $20 \%$ of the businesses closing worldwide and $26 \%$ in Brazil as of 2009 . Considering

\footnotetext{
${ }^{1}$ Researcher at GVcepe - Private Equity and Venture Capital Research Center at FGV-EAESP.
} 
that non profitable business status accounts for 30\%-40\%, there two factors accounts for almost $60 \%$ of the reason of businesses failure in Brazil - not to mention that there is a potential endogeneity since the fact of not having access to funding may mean not to invest and to grow properly, and as consequence make the business unprofitable. The ability to combine resources (financial, human, technology, information, natural, etc) to innovate is critical to blossom, develop competitive advantage, grow fast and survive.

Venture capital presents itself as a key alternative to address this issue, especially to companies without historical financial statements (i.e. startups) or companies without tangibles assets that could be used as bank loans' guarantees (Sahlman, 1990). Not to mention that venture capitalists provide not only capital but also assist the entrepreneurs on the decision making process in order to create successful businesses (Gorman and Sahlman, 1989). According to IHS Global Insight (2009), venture capital-backed enterprises generated around USD 3 trillion in revenues (21\% GDP) and employed over 12 million people in the United States in 2008. EVCA (2002) shows the PE/VC positive economic impact of PE/VC on companies' creation and growth.

Business environment for venture capital in Brazil has evolved in a consistent fashion over the last few years. According to EIU and LAVCA (2008) that qualifies venture capital environment in the region by identifying the positive and negative aspects for generating business within the industry in each country, Brazil jumped from 59 to 75 points in the ranking out of a possible 100 in only three years (2005 to 2008). More important than the number itself it is the development and consolidation of the venture capital environment in Brazil over the period in question.

\section{Literature Review}

It is well documented that venture capital has supported the creation and development of many of highly successful new revolutionary enterprises in the Human History, like Google, Microsoft, Netscape, Apple, eBay, Amazon, Sun Microsystems, Genentech, Yahoo, Intel, amongst others (Bygrave and Timmons, 1992; Gompers and Lerner, 2001b). Notwithstanding it is mainly associated with high-risk, potentially high-reward, leading edge technological projects (Gompers, 1994; Gompers and Lerner, 2002; Metrick, 2007), venture capital has also backed a large number of innovative service companies, such as Staples, Starbucks, FedEx, Home Depot and TCBY - The Country's Best Yogurt (Gompers, 1994; Gompers and Lerner, 2001b).

Venture capital investments benefit startups and SMEs (small and medium enterprises) that normally have difficult to access ordinary financing, especially in emerging markets, due to their lack of tangible assets to use as collateral, heavy reliance on R\&D and human resources, operating losses for many years, and higher survivorship risk than more mature companies (Premus 1985; Gompers, 1994; Gompers and Lerner 2001a; Gompers and Lerner 2001b; Hall 2002; Smith and Smith 2002; Leeds 2003). Different from bank loans and short term debts, venture capital will share upside and downside risks with the entrepreneur by taking an equity stake in the company and becoming a partner committed to its strong and sustainable growth (Engel, 2002; Gompers, 1994).

De Negri and Kubota (2008) argue that due its intangible profile, innovative enterprises face financing constraints. According to Ribeiro and Tironi (2006) and Melo (2007), the innovation financing gap in Brazil can be mitigated by venture capital. Campos and Barbieri (2002) and Titericz (2003) also argue that venture capital presents a very interesting alternative funding source for innovation in Brazil. For Portugal, Gaspar (2008) shows that venture capital not only increases the entrepreneurial activity in the economy, but also reduces the mortality rate of startups and SMEs. 
Figure 1: The J-Curve

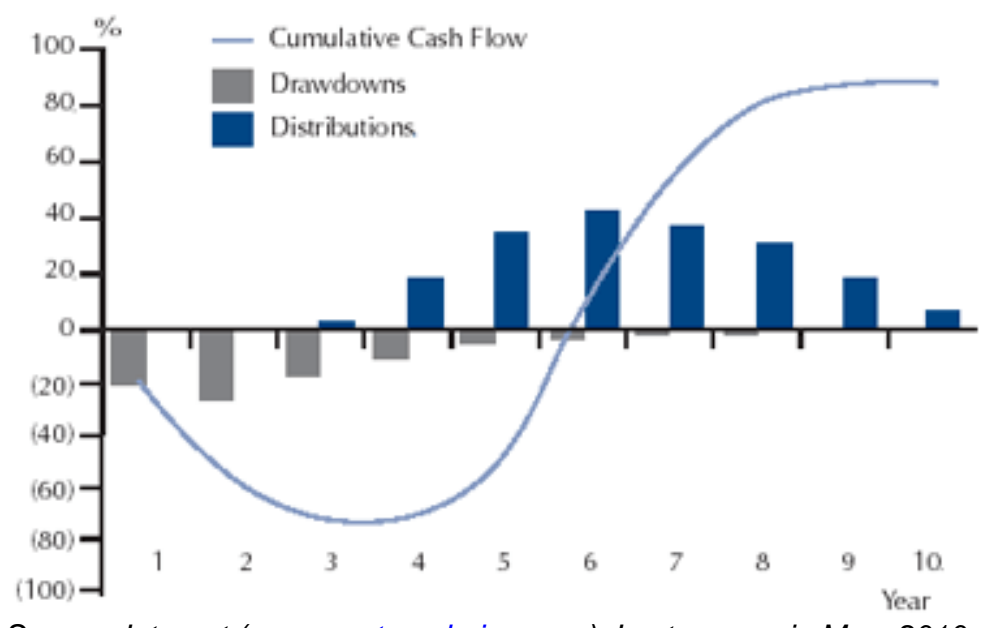

Source: Internet (www.venturechoice.com). Last access in May, 2010

Surpass the 'valley of death' (negative cash flows period) from the J-curve is one of startups main challenges which it isn't accomplished only due to capital. Notwithstanding the positive impact from money provided by venture capital firms to enterprises, these invested companies also benefits from a whole package of strategic resources that helps increase startup's survivorship rates and build successful enterprises: monitoring and performance tools, management professionalization, compensation arrangements, board of directors, budget structure, well established and high level networking, mentoring and advice to entrepreneurs, etc (Gorman and Sahlman 1989; Dotzler 2001; Gompers and Lerner, 2001b; Gompers and Lerner 2002; Keuschnigg, 2009). According to Bloom, Sadun and Van Reenen (2009), on average venture capital-backed firms are better managed than non-venture capital backed ones.

The main challenge of any company is to combine appropriate resources (human, technology, capital, information, natural, etc) is a very important competence to innovate and to gain competitive advantage. (Porter 1979; Barney 1986; Prahalad and Hamel 1989; Hamel and Prahalad 1993; Teece and Pisano 1994; Mahoney 1995; Teece et al 1997; Bartlett and Ghoshal 2002). Christensen and Overdorf (2000) identify three factors that affect companies' innovation: resources, processes and values. Hardagon and Sutton (2000) states that innovative companies hire people with complementary skills and backgrounds, and that innovation is easily fostered if the right incentives and rewards are given to people. Through venture capital it is possible to boost startups and SMEs growth compared to their peers (Hellman and Puri 2000; Engel 2002) which allow them to become more profitable (Sahlman 1990) throughout innovations.

Sorensen (2007) suggests that venture capital invest primarily in entrepreneurial innovative companies and it has substantial impact on development of new technologies, as Premus (1985) demonstrates venture capital and technological innovation growths are correlated. Kortum and Lerner (2001) show that venture capital-backed companies are involved in important innovations based on patent amount in the US, while Bowonder and Mani (2002) show the impact of venture capital on financing innovation in India, and Tykova (2000) demonstrates a positive relation between venture capital investments and patents creation in Germany. On the other hand, Hirukawa and Ueda (2008) establish that the causality relation between venture capital investments and innovation are far more complicated that showed by several studies, and Lerner (2002) also states that the venture capital impact in innovation is far from to be uniform.

Due to its importance to an economy, according to Keuschnigg (2003) policy makers have been fostering favorable entrepreneurial environment throughout venture capital to creating successful businesses worldwide. For example, Hirukawa and Ueda (2008) highlight the Yozma program in Israel and the SBIC (Small Business Investment Company) in the US, Lerner (2002) agrees that Government is highly interested on fostering innovation and support the PE/VC activity is a natural way to accomplish that goal, and Ramalho (2010) shows the positive influence from venture capital public policies on entrepreneurship in Brazil. Gompers (1994) concludes that "promoting an efficient venture capital sector should be the goal of any administration". 


\section{Methodology}

I conducted an empirical research which collected primary data from a sample of 127 private equity and venture capital (PE/VC) firms - $90 \%$ of the population - operating in Brazil as of June, 2008, independently of whether they have a local presence (office) and/or an investment vehicle already formed and operating. In other words, all PE/VC firms already defined and structured as such, even if they are still in the process of fundraising, were considered members of the Brazilian PE/VC industry. In addition, those PE/VC organizations that informed us that they are no longer operating in the industry, those that are still not actively looking for business in Brazil and/or that don't consider themselves managers of PE/VC investment vehicles were not considered in the population.

With these conditions and exclusions, the sample was composed of $127 \mathrm{PE} / \mathrm{VC}$ firms $(90 \%$ of the population) that fulfilled all the prerequisites required to be included in the survey. Each one of the 127 PE/VC firms filled out a questionnaire on the web which consisted of questions that supplied quantitative data regarding investment vehicles, portfolio companies, investments and exits. Then I conducted an exploratory analysis of the PE/VC impact on entrepreneurship in Brazil based on the portfolio companies' profile and the stock market dynamics from 2004 to 2008.

\section{Main Findings}

Over the last few years, driven by global liquidity and the strong growth of domestic economic indicators, the Brazilian PE/VC industry has gone through a very significant evolution. The growth of total committed capital has been impressive averaging 53.4\% per year since 2004 to reach USD26.65 billion by June 2008 , although it still represents only $1.7 \%$ of GDP compared to the world average of 3.7\% (NEF, 2008; Ramalho and Furtado, 2008). The great diversity of economic sectors constitutes an important aspect of the business model of the PE/VC industry. The 481 portfolio companies cover 26 industries and more than 40 sub-industries.

Table 1: Portfolio Companies

\begin{tabular}{|l|c|c|c|c|}
\hline \multirow{2}{*}{\multicolumn{1}{|c|}{ Industries }} & \multicolumn{2}{c|}{$\mathbf{2 0 0 4}$} & \multicolumn{2}{c|}{2008} \\
\cline { 2 - 5 } & Units & $\%$ & Units & $\%$ \\
\hline IT & 92 & $30 \%$ & 108 & $22 \%$ \\
\hline Industrial Products and Services & 41 & $13 \%$ & 63 & $13 \%$ \\
\hline Real Estate & 9 & $3 \%$ & 60 & $12 \%$ \\
\hline Communication & 7 & $2 \%$ & 32 & $7 \%$ \\
\hline Energy & 7 & $2 \%$ & 29 & $6 \%$ \\
\hline Agribusiness & 9 & $3 \%$ & 21 & $4 \%$ \\
\hline Financial Services & 10 & $3 \%$ & 20 & $4 \%$ \\
\hline Biotech & 10 & $3 \%$ & 19 & $4 \%$ \\
\hline Retail & 21 & $7 \%$ & 19 & $4 \%$ \\
\hline Food and Beverage & 12 & $4 \%$ & 17 & $4 \%$ \\
\hline Medicine & 8 & $3 \%$ & 15 & $3 \%$ \\
\hline Telecom & 28 & $9 \%$ & 13 & $3 \%$ \\
\hline Transportation & 11 & $4 \%$ & 13 & $3 \%$ \\
\hline Logistics & 7 & $2 \%$ & 12 & $2 \%$ \\
\hline Education & 3 & $1 \%$ & 9 & $2 \%$ \\
\hline Others & 31 & $10 \%$ & 31 & $6 \%$ \\
\hline TOTAL & $\mathbf{3 0 6}$ & $\mathbf{1 0 0} \%$ & $\mathbf{4 8 1}$ & $\mathbf{1 0 0 \%}$ \\
\hline
\end{tabular}

The IT and Electronics industry constitutes the largest portion of the companies in the PE/VC organizations' portfolios (22\% of the total), though in the last four years it has decreased in terms of its relative participation (it represented $33 \%$ in 2004), along with the considerable number of divestitures in this sector in three years.

A total of $51 \%$ of the industry's portfolio companies are more mature companies, $43 \%$ are Private Equity - Expansion and $8 \%$ are Private - Later Stage, but there also is a considerable volume of business in Venture Capital (34\%) with the greatest emphasis on the Early Stage (17\%). This denotes an important concentration on the initial and intermediate stages of entrepreneurial development guaranteeing the consolidation of the links that permit sustained industry growth over the long term. 
Figure 2: Portfolio Company Stages (as of June 30, 2008)

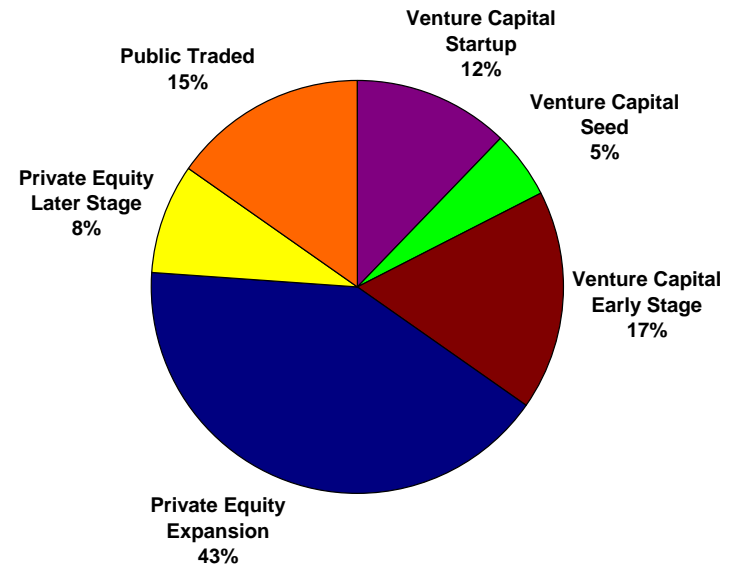

OBS: Considers the sample of 462 companies that reported their current stage of development (out of a total of 481 companies).

There is a considerable volume of business in Venture Capital (34\%) with the greatest emphasis on the Early Stage (17\%), in addition to $43 \%$ of Private Equity Expansion, mostly medium size companies. This denotes an important concentration on the initial and intermediate stages of entrepreneurial development guaranteeing the consolidation of the links that permit sustained industry growth over the long term.

Over the last four years, the proportion of portfolio companies with headquarters in the Southeast has grown significantly, going from $66 \%$ in 2004 to $80 \%$ in 2008 . Companies in the South have reduced their relative participation from $26 \%$ to $12 \%$ and the other regions together have maintained their proportion of $8 \%$ of the total of portfolio companies. The State of São Paulo has distinguished itself in the expansion of the Brazilian Private Equity and Venture Capital industry, not only by the fact that it contains many of the PE/VC organizations' headquarters, but also in terms of portfolio companies. Its relative proportion of portfolio companies increased from $45 \%$ in 2004 to $56 \%$ as of June 2008 .

Figure 3: Geographic Distribution of Portfolio Companies (as of June 30, 2008)
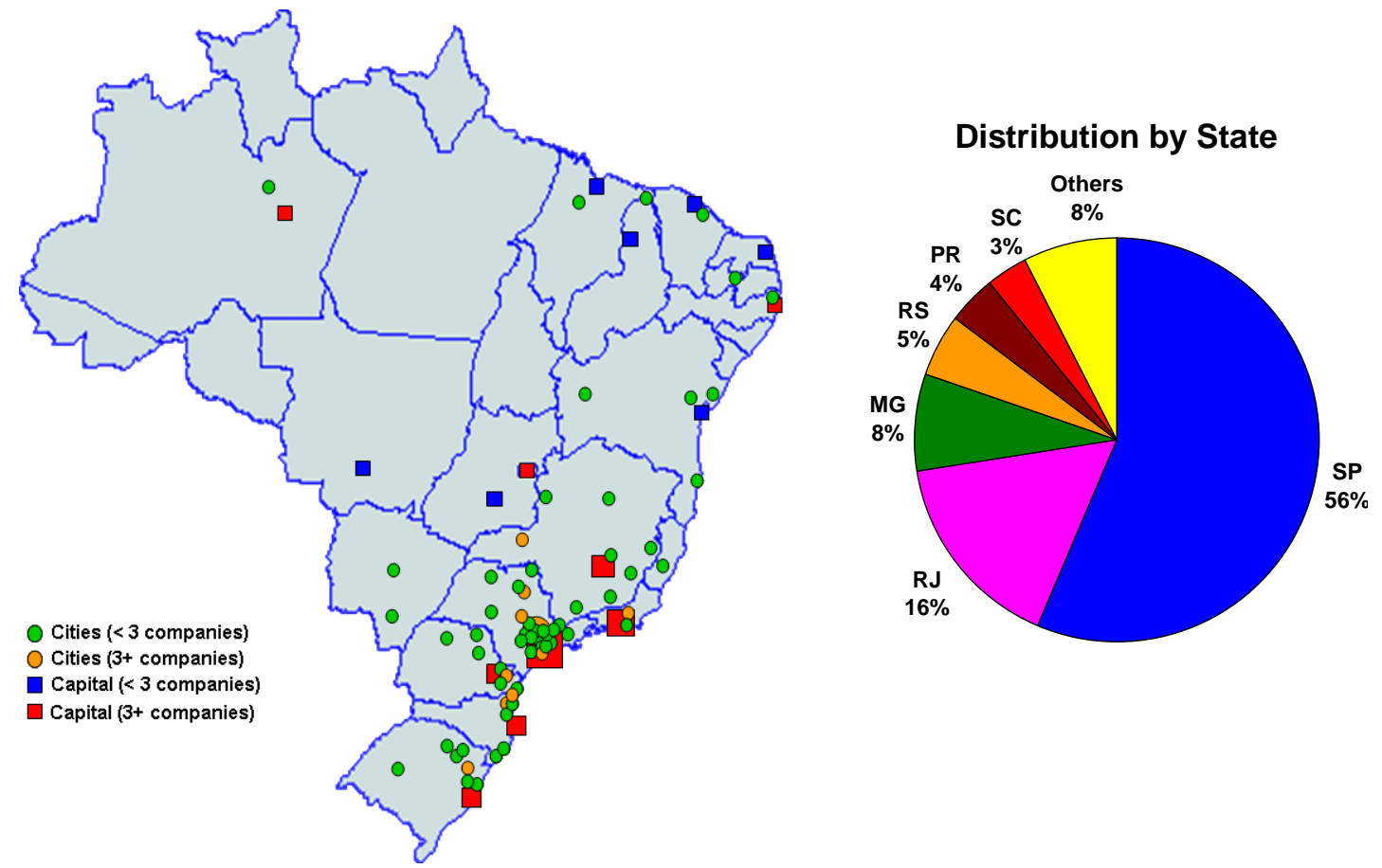

OBS: Considers 461 companies that reported the city where their headquarters is located (out of a total of 481 companies). 
Figure 4: Geographic Distribution of Business Incubators and Tech Parks in Brazil (as of 2009)

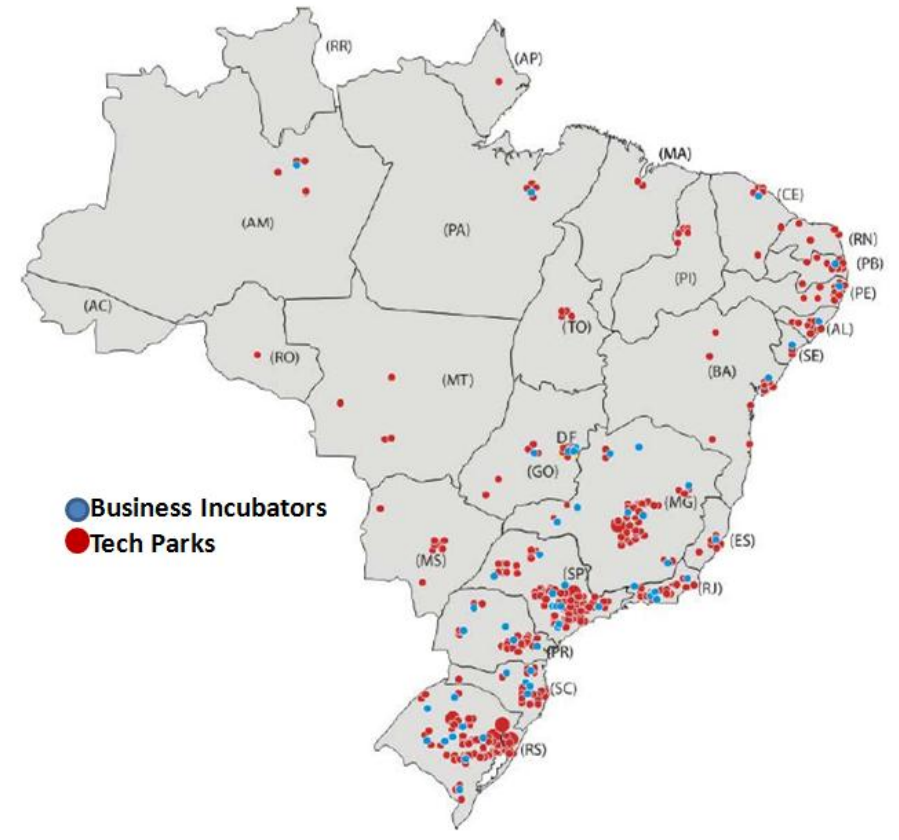

Source: Plonski (2009)

These numbers are especially intriguing due to the geographic distribution of business incubators and technological parks countrywide. Although there is an important presence of business incubators and tech parks in Santa Catarina, Rio de Janeiro and especially Minas Gerais and Rio Grande do Sul, there are a small number of PE/VC portfolio companies there. This phenomenon can also be observed in the Northeast region which holds a mediocre amount PE/VC portfolio companies in spite of the incubators and tech parks presence in the region (as shown on figure 5).

Figure 5: "Gap" regions from PE/VC portfolio companies and Tech Parks/Business Incubators

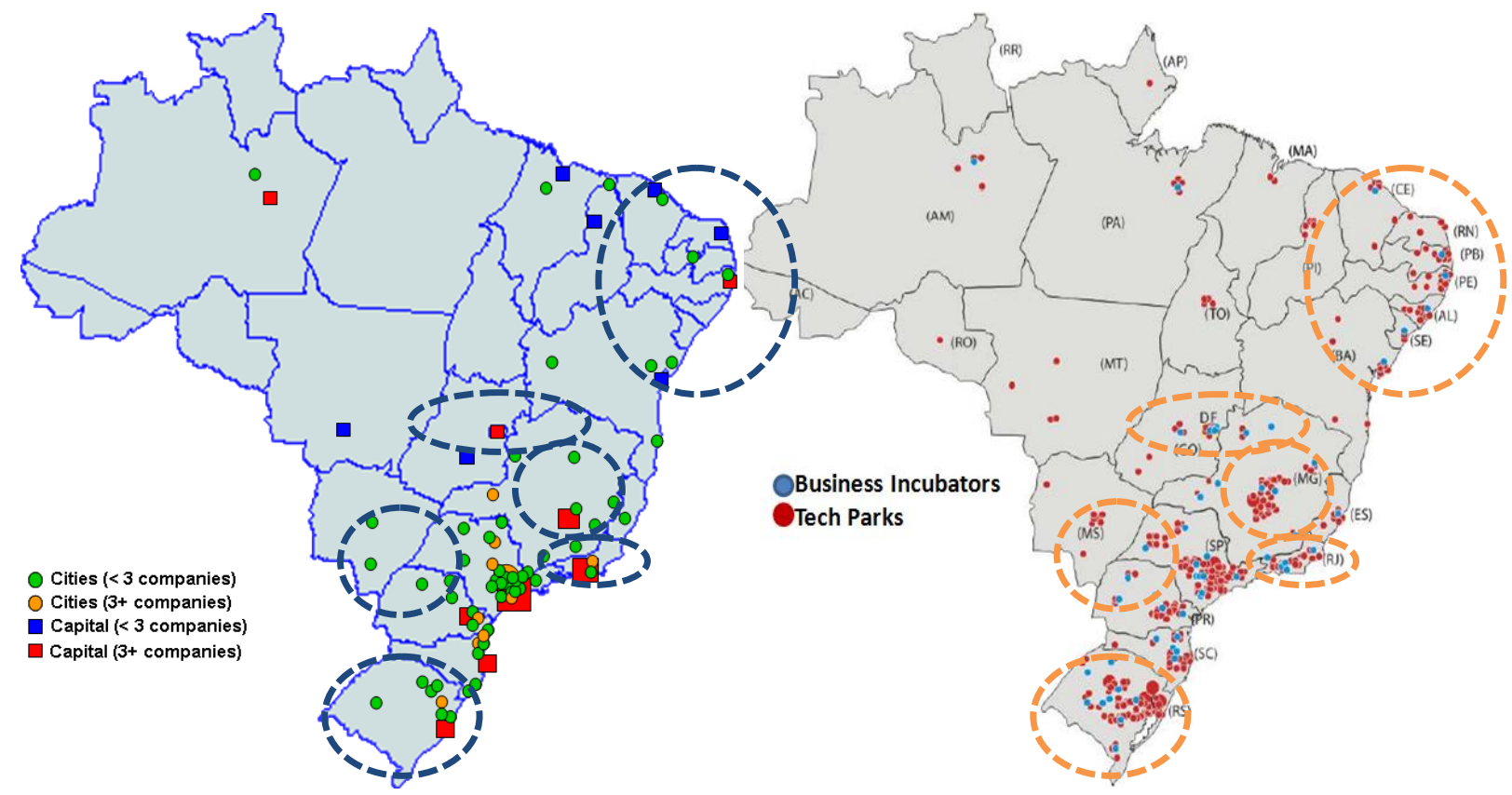

C- Indicates the regions with a "gap" (i.e. lot of tech parks/business incubators and just a few PE/VC-backed companies)

Source: Author's analysis 
Almost $40 \%$ of the investments in portfolio companies were made before 2005 , and thus are four or more years old. Considering that the investment vehicles in the venture capital industry last on average around five years, it is possible to expect an important flow of new exits over the next few years. As consequence, new investments shall be made by the PE/VC industry in Brazil and the incubators and tech parks may step in and present themselves as a viable alternative of deal flow.

Figure 6: Portfolio Companies Breakdown by Investment Year (as of June 30, 2008)

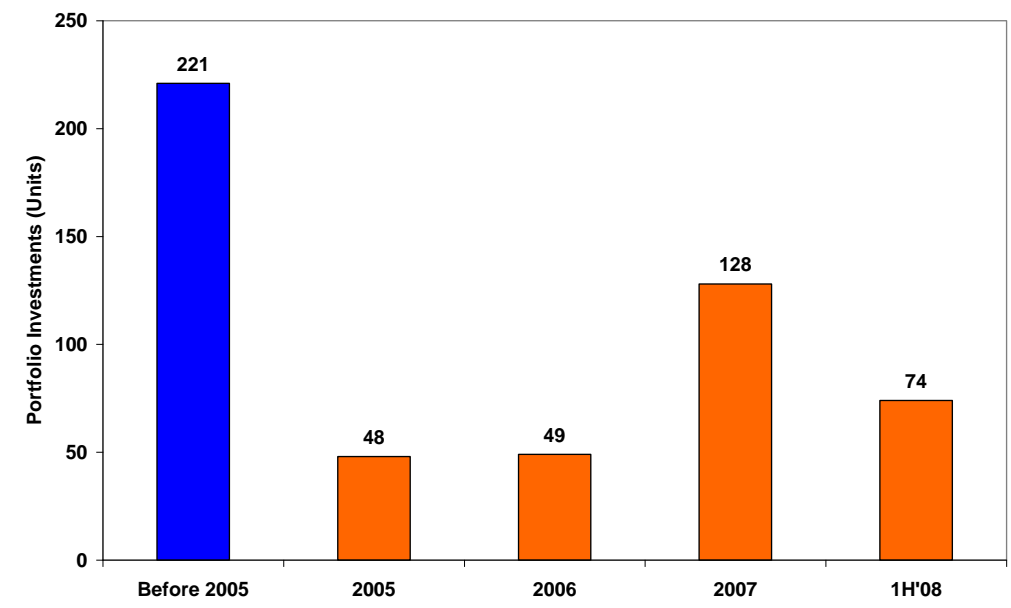

OBS: As of June 30, 2008 there were 520 ongoing portfolio company investments, of which 39 were joint investments (total number of companies: 481 ).

\subsection{The Impact on the Stock Market}

I obtained a sample of 111 exits ( 85 total and 26 partial) over the period of 2005 to June 2008 . Half of these exits were from Private Equity and $31 \%$ from Venture Capital. Of the 111 exits (total and partial), values were reported for 104 investments totaling USD2 billion over the period from 2005 and June 2008. Trade sales represented around $20 \%$ of the total number of exits in the industry over this period, while sales in the stock market represented $50 \%$ of the total quantity.

It is important to note that the mortality rate of the portfolio companies were reported at $6 \%$, much lower than $50-60 \%$ average from non-venture capital backed companies during the first three years of life. There are two arguing points contrary the representativeness of this number: (i) selection bias, since venture capitalists could invest only on the best companies with higher probability to survive; (ii) moral hazard, since venture capitalists may haven't inform those called "zombie" companies that have high probability of failure, but the venture capitalists don't admit so.

Figure 7: Number of Exits by Type (January 2005 to June 2008)

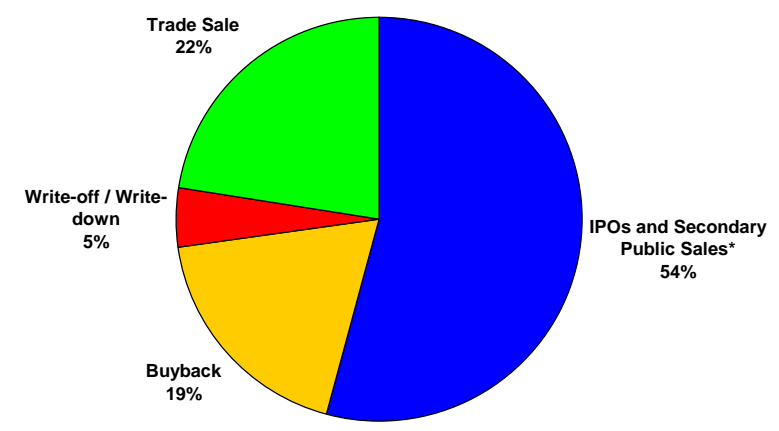

* Includes IPOs and secondary sales between funds.

OBS: Considers total and partial exits. 
IPOs are one of the natural exits for PE/VC investments worldwide; however it didn't constitute a viable alternative in Brazil during the 1980s and 1990s because of the volatile macroeconomic environment and high interest rates that prevailed in the country during this period. This is why few companies looked to the stock market for long term financing in Brazil, and consequently, the IPO market passed through a "nuclear winter" period.

Nevertheless, with the improvement in the macroeconomic scenario and the increase in global liquidity, along with the reduction of interest rates, the stock market stood out again as an alternative long term investment. In fact, in the beginning of 2004 the Brazilian stock market took on a new momentum with the wave of IPOs set off by the exits from PE/VC organizations. From 2004 to June 2008, 110 IPOs were taken to market raising BRL 88.5 billion, of which 39 companies had received $\mathrm{PE} / \mathrm{VC}$ investments prior to their public offering.

Figure 8: Number of IPOs

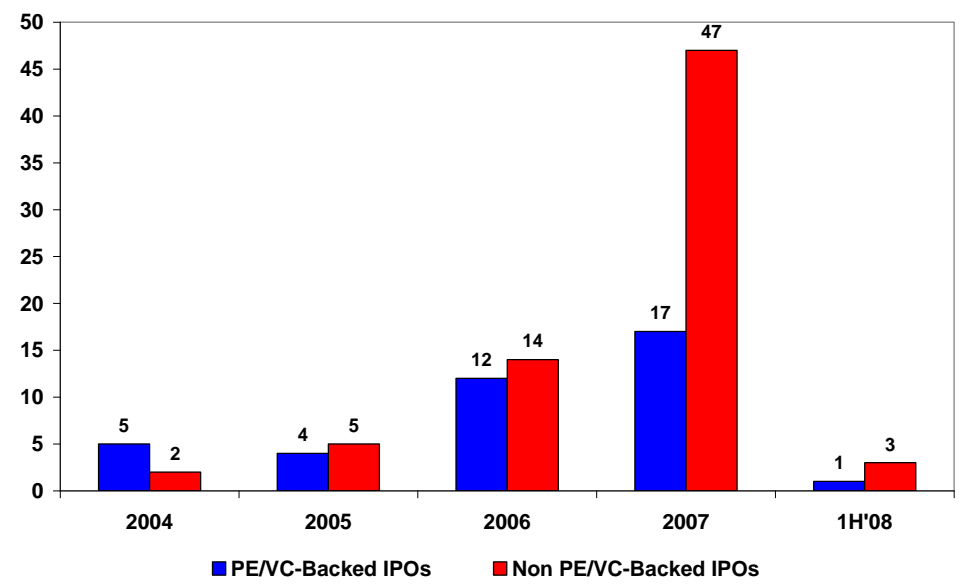

Source: Bovespa / Author's analysis

Figure 9: Money Raised through IPOs (BRL million)

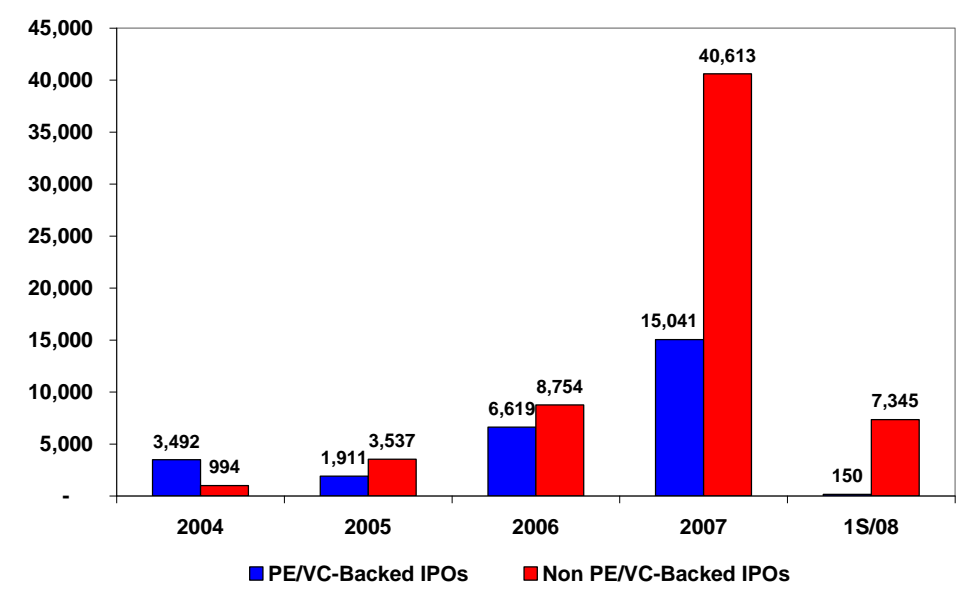

Source: Bovespa / Author's analysis

The total amount of money raised by companies that received PE/VC investments reached BRL 27.2 billion from primary and secondary offerings, equivalent to $31 \%$ of the total volume of IPOs made during this period. Between May 2004 and June 2008, companies that received PE/VC investments had an average return of $17.3 \%$ as opposed to $1.5 \%$ for the companies that did not receive PE/VC investments, with $67 \%$ of the returns being positive for those that had received PE/VC investments and $40 \%$ being positive for those that had not. 


\section{Conclusions}

It is well documented the impact of the venture capital industry in the creation and development of high successful innovative and high-tech companies like Google, Microsoft, Netscape, eBay, Amazon, Yahoo, Intel and Genetech. Not to mention that it has also supported non-tech, but highly innovative, service companies, such as Staples, Starbucks, FedEx, Home Depot and TCBY. Venture capital provides not only capital to the enterprises but also strategic resources that allow the invested companies to differentiate and pursue a competitive advantage against its peers showing an impressive level of not only technological but also process, management and product innovations.

In order to help startups and SMEs to surpass the 'valley of death', venture capitalists not only provide funding but also a whole package of strategic resources that help the invested companies to succeed. As consequence, some innovative enterprises have arise in Brazil in the past few years like Submarino, DHC Outsourcing, Akwan, Allelyx, Canavialis, Buscapé, Lupatech, Bematech, Mandic BBS, GOL and DASA, just to mention a few, leveraged by the local economy growth and monetary stability. There are almost 500 portfolio companies, of which over a third from high innovative and technological industries that have a strong potential to produce disruptive innovation.

In addition, the capital markets also benefited from the increase of venture capital activity since 2004 . Around one third of the IPO - Initial Public Offerings in Brazil were PE/VC-backed companies (BRL 27.2 billion). In also indicates that the public policy direct to the first stage of the PE/VC cycle (fundraising) also produced positive effect on its last stage (exit) in Brazil.

Due to its entrepreneurial vocation, several governments worldwide have elected the PE/VC as a key public policy toward innovation and entrepreneurship. Many have failed, but some succeeded as noted by Lerner (2009). Using public policies to foster PE/VC can be a disastrous waste of time and money, not to mention the real possibility to ruin any potential entrepreneurial and innovative initiatives. In emerging markets, this dilemma becomes even more dramatic since PE/VC can offer the only sustainable alternative to the financing gap faced by startups and SMEs. This is also the challenge for Brazil.

A very interesting characteristic about the local $\mathrm{PE} / \mathrm{VC}$ industry to be observed is the private equity expansion segment role, since it also invests in companies that would normally be considered venture capital. Notwithstanding the strong venture capital and private equity expansion dynamics in Brazil, the beginning of industry's value chain (angel and seed capital) still needs to be enhanced in order to secure a long term venture capital-back entrepreneurship model in the country. In addition, it should be investigated why industry's portfolio is highly concentrated in the southeast (mainly in São Paulo).

The relationship between incubators/tech parks and the PE/VC industry in Brazil should also be addressed. The PE/VC organizations in Brazil usually complain about their poor deal flow situation which difficult the 'natural' cycle of the industry and as consequence a positive entrepreneurial environment in the country. The low quality of business plans and the difficult to find business-oriented entrepreneurs are two examples of the bottlenecks faced by the PE/VC industry. On the other hand, hundreds of entrepreneurs, especially those high tech ones, complain that the PE/VCs aren't able to analyze their businesses properly as most of them are former investment bankers or asset managers with no entrepreneurial experience. Indeed, the gap between entrepreneurs and venture capitalists is another 'valley of death' for the highly innovative entrepreneurship in Brazil that needs to be surpassed. Notwithstanding the present situation, the incubators and tech parks may partner with the $\mathrm{PE} / \mathrm{C}$ industry in order to change that scenario (i.e. "gap" regions) in the next years.

It should be questioned whether the incubators, and especially tech parks, are prepared to support their companies toward a PE/VC investment, assuming that this type of financing may offer not only capital but also business orientation to the entrepreneurs. Nevertheless, an effective policy toward a venture capital-backed entrepreneurship model should be organized by the PE/VC industry together with the incubators, tech parks and other key agents in that equation. 


\section{References}

ABRAPP. (2008). "Consolidado Estatístico - Junho 2008". ABRAPP - Brazilian Association of Pension Funds report.

Andreassi, T. and Siqueira, E. (2006). "The funding of new technology-based firms in Brazil". International Journal of Entrepreneurship and Innovation Management 6(4/5), 369-382.

Barney, J. (1986). "Strategic Factor Markets: Expectations, Luck and Business Strategy". Management Science.

Bartlett, C. and Ghoshal, S. (2002). "Building competitive advantage through people". MIT Sloan Management Review.

Bloom, N., Sadun, R. and Van Reenen, J. (2009). "Do Private Equity Owned Firms Have Better Management Practices?". Centre for Economic Performance. Occasional Paper, n.24.

Bosma, N. and Levie, J. (2010) "Global Entrepreneurship Monitor 2009 Global Report". London: Global Entrepreneurship Research Association.

Bowonder, B and Mani, S. (2002). "Venture Capital and Innovation: The Indian Experience". In: Financial Systems, Corporate Investment in Innovation and Venture Capital". UNU/INTECH research project.

Bygrave, W. and Timmons, J. (1992). "Venture Capital at the Crossroads". Harvard Business School Press.

Campos, S. and Barbieri, J. (2002) "Capital de risco para empresas emergentes de base tecnológica: uma avaliação da atual legislação brasileira”. XXII Simpósio de Gestão da Inovação Tecnológica.

Christensen, C. and Overdorf, M. (2000). "Meeting the Challenge of Disruptive Change". Harvard Business Review, Mar-Apr.

Dotzler, F. (2001). "What Do Venture Capitalists Really Do, and Where Do They Learn to Do It?". Journal of Private Equity. Winter.

EIU and LAVCA. (2008). "The Scorecard in the Private Equity and Venture Capital Environment in Latin America and the Caribbean". EIU - Economist Intelligence Unit and LAVCA - Latin American Venture Capital Association report.

EMPEA and Coller Capital. (2010). "Emerging Markets Private Equity Survey - 2010". EMPEA Emerging Markets Private Equity Association report.

Engel, D. (2002). "The Impact of Venture Capital on Firm Growth: An Empirical Investigation". Centre for European Economic Research, Discussion Paper 02-02.

EVCA. (2002). "Survey of the Economic and Social Impact of Venture Capital in Europe". EVCA European Venture Capital Association research paper.

Gaspar, F. (2008). "Fomentar o Empreendedorismo através do Capital de Risco e da Incubação de Empresas: um Estudo Empírico em Portugal". Revista Portuguesa e Brasileira de Gestão. Jul/Sep, 2008.

Gorman, M. and Sahlman, W. (1989). "What Do Venture Capitalists Do?" Journal of Business Venturing.

Gompers, P. (1994). "The Rise and Fall of Venture Capital". Business and Economic History 23(2), 1 18. 
Gompers, P. and Lerner, J. (2001a). "The Money of Invention". Harvard Business School Press.

Perspectives 15(2), 145-168 (2001b). "The Venture Capital Revolution", Journal of Economic (2002). "The Venture Capital Cycle", MIT Press, Cambridge.

Hall, B. (2002). "The Financing of Research and Development". NBER Working Paper 8773.

Hamel, G. and Prahalad, C. (1993). "Strategy as Stretch and Leverage". Harvard Business Review, Vol.71(2), pp.75-84.

Hardagon, A. and Sutton, R. (2000). "Building an Innovation Factory". Harvard Business Review, MayJune.

Hellmann, T. and Puri, M. (2000). "The Interaction between Product Market and Financing Strategy: The Role of Venture Capital". Review of Financial Studies 13, 959-984.

Hirukawa, M. and Ueda, M. (2008). "Venture Capital and Innovation: Which is First?". http://ssrn.com/abstract=1242698

IHS Global Insight. (2009). "Venture Impact - The Economic Importance of Venture Capital-Backed Companies to the U.S. Economy". NVCA - National Venture Capital Association report. $5^{\text {th }}$ Edition.

Keuschnigg, C. (2003). "Public Policy and Venture Capital Innovation". RICAFE Working Paper 004. . (2009). "Public Policy, Venture Capital and Entrepreneurial Finance" forthcoming in: Cumming, D. (ed.), "Companion to Venture Capital". New York: Wiley.

Kortum, S. and J. Lerner. (2001). "Does Venture Capital Spur Innovation?" in G. Libecap, ed., Entrepreneurial Inputs and Outcomes, Vol. 13, Amsterdam, Elsevier.

Leeds, R. (2003). "Financing Small Enterprises in Developing Nations". Transnational Publishers, New York.

Lerner, J. (2002). "Boom and Bust in the Venture Capital Industry and the Impact on Innovation". Harvard NOM Working Paper No. 03-13. (2009) "Boulevard of Broken Dreams". New Jersey: Princeton University Press.

Mahoney, J. (1995). "The Management of Resources and the Resources of Management". Journal of Business Research. Vol. 33, pp.91-101

Melo, L. (2007). "Inovação e Financiamento no Brasil: uma Análise do Sistema de Financiamento à Inovação no Brasil". XII Seminario Latino-Iberoamericano de Gestión Tecnológica - ALTEC.

Metrick, A. (2007). "Venture Capital and the Finance of Innovation". John Wiley and Sons, Inc.

Negri, J. and Kubota, L. (2008). "Políticas de Incentivo à Inovação Tecnológica”. IPEA, Brasília.

NEP. (2008). "Black Economic Empowerment and Private Equity in South Africa". National Empowerment Fund report.

Pacheco, E. and Spritzer, I. (2009). "Mapeamento do fomento a Inovação Tecnológica no Brasil". Revista INGEPRO, Vol.1, n.4.

Plonski, G. (2009). "Incubadoras de Empresas y Parques Tecnológicos en Brasil". RedEmprendia Technical Meeting at USP, São Paulo. Available at:

http://www.inovacao.usp.br/redemprendia/files/IncubadorasdeEmpresasyParquesTecnologicos.pdf 
Porter, M. (1979). "How Competitive Forces Shape Strategy". Harvard Business Review. Vol.57(2), Mar-Apr, pp. 137-145 . (1990). "The Competitive Advantage of Nations". New York: Free Press. 1990

Prahalad, C. and Hamel, G. (1989). "The Core Competence of the Corporation". Harvard Business Review. Vol. 68(3), pp 63-76.

Premus, R. (1985). “Venture Capital and Innovation”. USGPO, Washington. D.C.

Ramalho, C. (2010). "Fostering Innovation and Entrepreneurship in Brazil through Private Equity and Venture Capital Public Policies". Available at SSRN: http://ssrn.com/abstract=1607223

Ramalho, C. and Furtado, C. (2008). "Overview of the Brazilian Private Equity and Venture Capital Industry - December, 2008". GVcepe - Private Equity and Venture Capital Research Center at FGVEAESP. Research report.

Ribeiro, L. and Tironi, L.F. (2006). "The Role of Venture Capitalists in the Identification and Measurement of Intangible Assets" Available at SSRN: http://ssrn.com/abstract=965594

Sahlman, W. (1990). "The Structure and Governance of Venture Capital Organizations. Journal od Financial Economics". Vol. 27(2), pp. 473-521.

Schumpeter, J. (1934). "The Theory of Economic Development". Oxford University Press.

Smith, R. and Smith, J. (2002). “Entrepreneurial Finance”. Wiley, New York

Sorensen, M. (2007). "Learning by Investing: Evidence from Venture Capital". Swedish Institute for Financial Research, n.53.

Teece, D. and Pisano, G. (1994). "The Dynamic Capabilities of Firms: An Introduction, Industrial and Corporate Change”. Vol. 3(3), pp.537-556.

Teece, D. and Pisano, G. and Shuen, A. (1997). "Dynamic Capabilities and Strategic Management". Strategic Management Journal, Vol.18(7), pp. 509-533.

Titericz, R. (2003) "Caracterização dos Fundos de Investimentos de Capital de Risco". Dissertação de Mestrado em Engenharia de Produção. Universidade Federal de Santa Catarina, Florianópolis.

Tykvova, T. (2000). "Venture Capital in Germany and its Impact on Innovation". http://papers.ssrn.com/paper.taf?abstract_id=235512 